\title{
FINTECH TOOLS TO REGULATE GRAY EXPORTS OF MILITARY AND DUAL USE GOODS AND TECHNOLOGIES
}

\author{
Viktoriya Gura ${ }^{1}$, Vitalii Novytskyi ${ }^{2}$, Alim Sizov ${ }^{3}$
}

\begin{abstract}
This article reviews challenges of monitoring and regulation of military and dual use goods and technologies in Ukraine. These challenges are not new; their different aspects have been analyzed previously by many Ukrainian researchers, such as G. Androshchuk, O. Fradynskyi, I. Anokhin, V. Davydovskyy and more, but all earlier analyses, while looking into theoretical and practical aspects of military and dual use goods and technologies export per se, left aside economic and financial aspects of this problem, which are in the focus of our investigation. The object of the study is the export of military and dual use goods and technologies. The subject of the study is the FinTech tools that can be applied to analysis of export of military and dual use goods and technologies. The aim of the research is to analyze the current situation in export of military and dual use goods and technologies and based on results of analysis to outline the FinTech tools that will be useful to evaluate and regulate gray exports of military and dual use goods and technologies. The methodology of research is based on economic analysis in which we have applied an alternative approach to assessing key indicators. Firstly, we determined government budget military expenditure and then compared it with the scope of relevant exports. Further, we analyzed the black market of military and dual use goods and technologies based on the data obtained from the Ministry of Internal Affairs. This analysis demonstrated that official numbers represent only $10 \%$ of the total expected amount of military and dual use goods and technologies export; the balance is shared between the domestic black market and gray exports. As result of the research we propose modern FinTech tools, including financial markers and the BlockChain technology, as instruments to detect such gray exports. Financial markers are specific FinTech indicators making banks aware that a transaction involves transfer of military or dual use goods or technologies and therefore requires special attention (to verify whether the company has an appropriate license or whether a license is needed for the transaction etc.) BlockChain is the best solution for tracking the financial marker information since it supports storage of information about the whole transaction chain and analysis of this information on any transaction stage. BlockChain technology can generate information on possible gray exports automatically and chain breaks (where the end user does not typically use or sell military or dual use goods or technologies but is a vendor of conventional goods or technologies).
\end{abstract}

Key words: dual use goods and technologies, military goods and technologies, Ukraine, export, crosscountry trade.

\section{JEL Classification: $\mathrm{O} 23, \mathrm{O} 33$}

\section{Introduction}

Export control of military and dual use goods in the international trade is a problem that is versatile and complex but not new. In the present day Ukraine, the study of this subject is focused on analysis of theoretical concepts and basic components of military and dual use goods and technologies export; in the meantime, there

Corresponding author:

${ }^{1}$ Taras Shevchenko National University of Kyiv, Ukraine.

E-mail: viktoriyagura2016@gmail.com

ORCID: https://orcid.org/0000-0002-4870-4037

${ }^{2}$ University of State Fiscal Service of Ukraine, Ukraine.

E-mail: vitnov11@gmail.com

ORCID: https://orcid.org/0000-0003-4072-6941

${ }^{3}$ Military Institute of Taras Shevchenko National University of Kyiv, Ukraine.

E-mail: alik_sizov@ukr.net

ORCID: https://orcid.org/0000-0002-6400-3951 has been no economic or financial analysis of this subject based on a key risk and market trend review in application to the Ukrainian military industry - this outlines both the focus of our research and its relevance and novelty.

The purpose of this study is to assess the real volume of military and dual use goods and technologies export and to develop FinTech instruments and mechanisms 
for its control. In order to achieve this goal, we need to analyze actual data on military and dual use goods and technologies export, to identify and evaluate alternative indicators of international transfers of such goods that bypass customs, and to find or develop reference points for the government to control export transactions involving military and dual use goods and technologies. Method used in this research is to extrapolate data received from the customs regarding methods and scopes of customs and export control evasion, as well as relevant information from other government authorities, on military and dual use goods and technologies export data to assess actual volume of export transactions involving these goods and technologies.

Literature Review below provides analysis of available theoretical framework and reviews studies of the subject by well-known experts. The Method section builds on this theoretical background to outline the research methodology used to derive the results of the study. These results are analyzed in the Discussion section together with apparent trends and points of influence available to government authorities; the results are further outlined in the Conclusions section.

\section{Literature review}

As it has been already mentioned in the Introduction, export control of dual use and military goods and technologies is not a novel challenge, which makes it neither less complex nor better regulated or explored. The principal difficulty lies in the practical dimension, since essential commodity descriptions making it a dual use or military good are information of technical nature, thus, any inquiry into economic or financial aspects here would be futile. Dual use and military services and technologies make situation even more complicated: in case of academic research resulting in a new technology or in respect of a service, a clear distinction can be made based on their military application, however, dual use technologies and services, being intangible, are practically untraceable.

Nevertheless, academic research in the area of economy or finance, covering the international trade sector in question, exist and generally use corpus of terminology and specific concepts pertaining to national security (and economic security as one of its components) as apply to exports and imports of dual use or military goods and technologies.

Specifically, according to S. Mochernyi (2000), export control is defined as a system of administrative, legal and economic arrangements made by the state to prohibit, restrict or control export of commodities. At the same time, researchers S. Galaka, O. Gryshutkin, G. Perepelytsia and O. Siver (2012) believe that "export control is an aggregate of international laws, contractual and political obligations and measures to control international transfers and use of military goods, dual use goods and other goods "sensitive" from security, proliferation or terrorism perspective. The goal of such measures is to mitigate risk of use of military power, proliferation of weapons of mass destruction or their delivery means and to reduce risk of use of "sensitive" goods for terrorist purposes."

O. Fradynsky (2013) defines "state export control" as "... a set of measures to control international transfers of goods or their use by legal entities or individuals, implemented by a specially designated executive authority for state export control or other government authorities to protect national security interests and to comply with international obligations of Ukraine...."

Furthermore, state export control pursuant to the Law of Ukraine (2003) is "...a set of measures to control international transfers of goods, their use by legal entities or individuals, applied by a central executive authority responsible for implementation of the government policy in the state export control and by other government authorities to protect national security interests and to comply with international obligations of Ukraine...."

State export control methods include:

- commodity identification that involves matching specific goods intended for international transfer against commodity descriptions on the lists of commodities subject to state export control;

- licensing or approval of international commodity transfers or negotiations for such transfers;

- customs control and customs clearance of goods in accordance with applicable law;

- application of sanctions against business entities who are in conflict with the transfer procedure prescribed by export control laws.

I. Anokhin and V. Davydovskyy (2015), researchers working on certain aspects of the Ukrainian export control system structure, have developed a general theory of the export control system structure in Ukraine and applied this theory to assess effectiveness of the export control system in controlling export of nuclear material, equipment and technologies from Ukraine.

At the same time, review of existing sources shows that economic and, particularly, financial aspects of export control over dual use or military goods and technologies remain largely unexplored. This results from a number of factors including indirect sources of information on dual use goods exports, major time gap before disclosure of consolidated data on dual use and military goods and technologies trade operations, lack of extended information on dual use or military technology trade per se, etc.

We have performed an economic and financial analysis of this sector on the basis of available indirect data and alternative indicators, that could be extrapolated on dual use and military goods and technologies export transactions, in order to identify points of financial impact by the government. 


\section{Analysis of exports of military and dual use goods and technologies}

For the purpose of further analysis, the subject matter of our study will be divided into subcategories to include "military goods," "military technologies," "dual use goods" and "dual use technologies."

Based on information available on export transactions closed between 2013 and 2018, no military technologies have been traded in Ukraine. This could signify both low interest of international partners to novel Ukrainian military technologies and sufficient level of national security mitigating risk of technology leak.

On the other hand, sales of military goods occur on a continuous basis, with new contracts signed every year. According to the State Service for Export Control of Ukraine (SSECU) and Stockholm International Peace Research Institute (SIPRI), Ukraine is a large exporter of military goods, although 2013-2018 saw a reduction in the scope and value of export transactions from 674 million USD in 2013 to 91 million USD in 2018. As for illegal circulation of military goods in Ukraine, the market of weapons, ammunitions and military explosives was between 120 million and 160 million USD in 2018 and surged more than threefold in 2019, which is evidenced by the growth in illegal weapons seizures from 5 thousand units in 2018 to 16 thousand in 2019, according to O. Klymchuk (May 2020).

The alternative analysis below, based on the state military expenditure, military goods export amount and the size of the shadow market of military goods, will be used to support the above results.

According to the data of the State Statistics Service of Ukraine and the State Treasury of Ukraine concerning state budget expenditure and of SIPRI concerning official exports of military goods, given in Table 1 below, the military expenditure has been growing continuously since 2014 to reach $3.4 \%$ of the Ukrainian GDP in 2019, making 5.1 billion USD in absolute terms; at the same time, export of military goods has seen continuous decline since 2014.

The growing expenditure to provide Ukraine's armed forces with required military goods would seem natural considering ongoing hostilities within the Special Operations Zone in eastern Ukraine. However, this hypothesis is not backed by the published reports on new armament deliveries, since no new main combat vehicles (including state-of-the-art Oplot battle tanks) were supplied to the armed forces during 2013-2018, and since novel weaponry developed by the local military industry remains too expensive for the Ukrainian military. Instead, the armed forces receive modernized but still obsolete Bulat battle tanks - the upgraded T-64s, according to D. Popovych (November, 2019).

The diminishing scope of official military goods exports, against the backdrop of growing production of these goods with the substantially lower growth rate of their domestic consumption, signifies the presence of a domestic shadow market of military goods. As a result of the embargo against Russia - formerly a strategic importer of Ukrainian military goods - active since 2014 (SSECU, 2018), military goods export rates dropped by $45 \%$. This drop was mitigated in subsequent years owing to new markets allowing to earn $41 \%$ back.

Similarly, in absence of new restrictions and given doubled government allocations to the military sector one could have expected an increasing amount of military goods export due to more product offerings and higher science-intensity of these offerings. The moderate growth model below, based on the military sector funding at the rate of 3.1-3.3\% of the GDP, shows that the pre-war military goods exports were supposed to recover in 2018 and reach 780-820 million USD at 2019.

On the other hand, a chain growth model below provides an alternative estimate of the military goods export in 2019 at the level of 1.1 billion USD.

Considering that Ukraine has still territories out of control of official government, where active hostilities are in progress, the former of the two methods seems more realistic, however, even in its case the real export of military goods is only $15 \%$ of the expected level. Obviously, the gap unaccounted for indicates the size of the domestic black market and gray exports. The estimated scope of the black market in 2019 was, according to the indirect Ministry of Interior data, in excess of 360 million USD; thus, the estimated gray export amount exceeds 370 million USD.

In the 2020-2021 projection, the moderate growth model shows 980 million USD for 2020 and 1,120 million USD for 2021 and the chain growth model, respectively, 1,580 million USD for 2020 and 1,720 million USD for 2021, however, confidence level of these projections is no more than $10 \%$, therefore it was decided to wait until actual 2019-2020 indicators become available before populating the projection model.

The next subcategory is dual use technologies. We will agree with G. Androshchuk (2018) in that analysis of patents registered in Ukraine is the most effective way

Table 1

Distribution of military expenditures in GDP and value of military goods export in Ukraine in 2013-2019

\begin{tabular}{|l|c|c|c|c|c|c|c|}
\hline \multicolumn{1}{|c|}{ Year } & 2013 & 2014 & 2015 & 2016 & 2017 & 2018 & 2019 \\
\hline Military expenditure as a GDP share & $1.6 \%$ & $2.2 \%$ & $3.3 \%$ & $3.2 \%$ & $2.9 \%$ & $3.2 \%$ & $3.4 \%$ \\
\hline Military goods export, mln USD & 674 & 622 & 343 & 487 & 306 & 195 & 91 \\
\hline
\end{tabular}




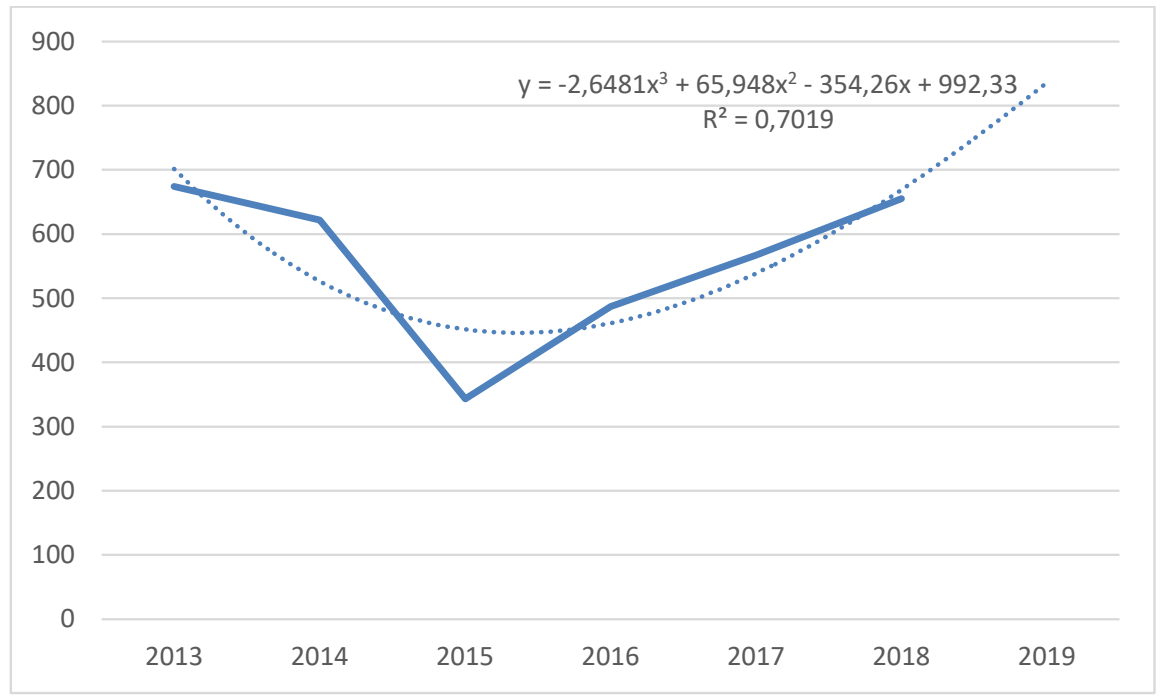

Figure 1. Ukrainian military goods export moderate growth model for 2013-2019, million USD

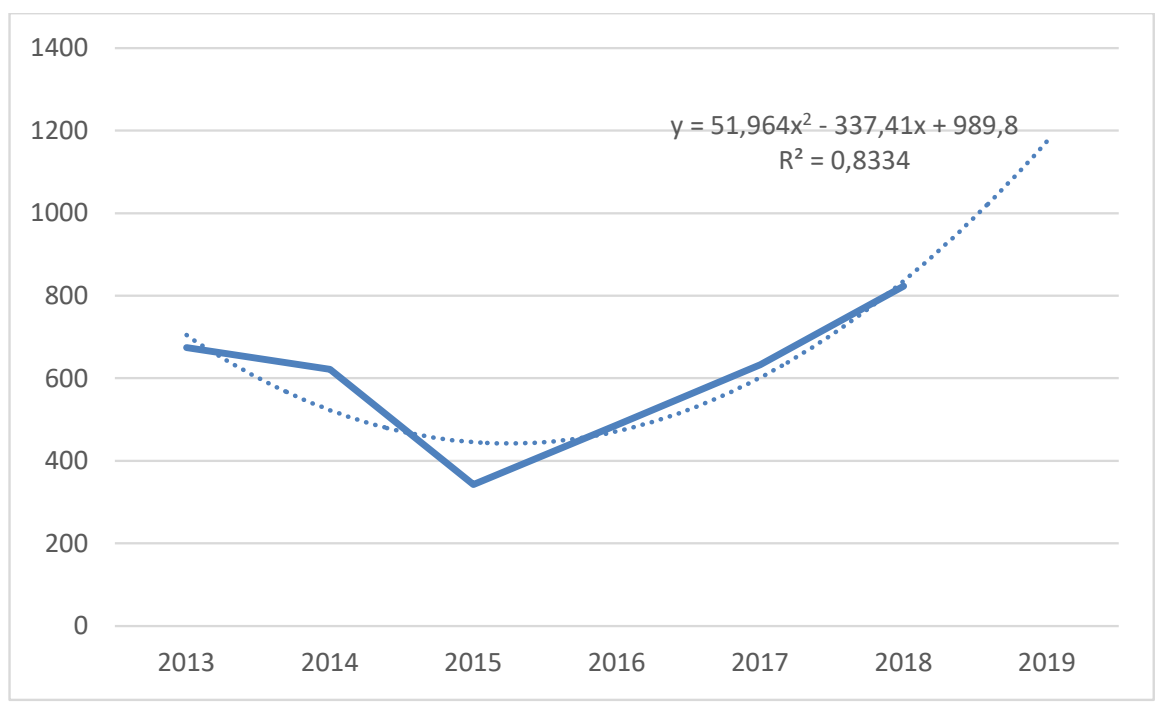

Figure 2. Ukrainian military goods export chain growth model for 2013-2019, million USD

to investigate the size of exports of dual use technologies developed in Ukraine. In this case the most effective way to evaluate the financial side of the exports is from the perspective of investments and international cash flows targeted at companies or individuals who are involved in research activities.

As could be seen, both the number of invention and useful model registration applications and the number of patents issued have been sliding down during
2015-2017. At the same time, the bulk of the applications and patents were associated with individuals (from $65 \%$ to $80 \%$, depending on the class and the year), which means that most companies involved in $\mathrm{R} \& \mathrm{D}$ register patents in the names of individuals in this case a technology may be sold under a nonexclusive license or a license with partial transfer of rights in the framework of a works or services contract. The other reason is that an individual submission is

Table 2

Patent applications submitted and patents obtained for inventions and utility models in classes F41 "Weapons" and F42 "Ammunitions; Explosives"

\begin{tabular}{|l|c|c|c|c|c|c|c|}
\hline & 2019 & 2018 & 2017 & 2016 & 2015 & 2014 & 2013 \\
\hline Submissions in class F41 & 69 & 25 & 19 & 52 & 86 & 84 & 66 \\
\hline Submissions in class F42 & 38 & 32 & 13 & 38 & 39 & 32 & 39 \\
\hline Patents issued in class F41 & 14 & 28 & 29 & 71 & 103 & 68 & 66 \\
\hline Patents issued in class F42 & 9 & 27 & 25 & 41 & 25 & 42 & 36 \\
\hline
\end{tabular}


substantially cheaper than a corporate submission (40 UAH or more for individuals versus $600 \mathrm{UAH}$ or more for legal entities). Furthermore, although the above categories cover military technologies no government control is applied to registration of relevant inventions and useful models by individuals, as opposed to legal entities.

On the other hand, there is no control whatsoever of investments in $\mathrm{R} \& \mathrm{D}$ companies who develop military technologies in exchange for research results without Ukrainian patent registration, as it is hard to determine in advance whether the prospective technology would qualify as a military technology. Besides, a technology could be easily requalified as a dual use or even non-military technology in the course of research.

Examples could be found even in the UAV remote control technology domain. The Ministry of Defense of Ukraine organized several tenders for the development of both UAVs and their control software in the course of 2018-2019. For a bidder technology not selected by the Ministry of Defense Tender Commission, it takes a minimum effort to be requalified as a nonmilitary technology: it can be easily adapted for use on civilian quadrotors carrying cameras and sensors. Such a technology may be exported in an uncontrolled manner, even though original development was specifically intended for military use.

The analysis of direct investments into Ukraine shows that academic research and development accounted for $3.2 \%$ of the total amount of foreign investments in 2018 (reaching 93.2 million USD) (Shtepenko, Zaburayeva, 2019). However, as we add R\&D funded under innovative programs, this number will increase to $6.8 \%$ (according to K. Markevych, 2020), or to 198.1 million USD in absolute terms. Based on state budget expenditure statistics, the military sector accounted for $15.6 \%$ of the Ukrainian economy in 2018, whereas the 2018 funding of research and development of new weapons and materiel was $9 \%$ of the total defense expenditure in Ukraine, which on average was $30 \%$ higher than the average percentage in any other economy sector in the same year. Extrapolation of this data shows that $15.6 \%$ to $18.2 \%$ of foreign investments in the Ukrainian science was targeted at military or dual use technology research, making 31 to 36 million USD in absolute terms. On the other hand, it is a challenging task to track exports of such technologies: they include back transfers of research results not patented in Ukraine, making identification of the real size of export of military of dual use related technologies impracticable.

\section{Discussion}

Based on research of novel financing technologies and the status of the military and dual use goods and technologies export control we would like to offer a specialized module for the national payment system to track cash flows related to military and dual use technologies. The concept of operation of this financial module is based on the fact that domestic trade operations involving military and dual use goods generate cash flows that will be marked by the module to identify the specific cash flow as being related to military or dual use goods within the payment system. Similar markers should be applied to bank accounts of entities who produce goods or provide services having military or dual use and of their business partners (buyers) and all other participants in the sales chain. This financial marker should build on the BlockChain technology and should contain either information on parties of all previous military or dual use goods transfers or active links to associated elements of the same military or dual use goods transfer chain allowing instantaneous access to all necessary information. Service of such a BlockChain network may be imposed on the banks, since such markers are private banking information not disclosed to clients but made available to government controlling authorities (National Bank, State Fiscal Service and SSECU). The bank will apply the marker of a military or dual use good manufacturer based on a Standard Activity Classification Code referring to military or dual use goods production and on the SSECU database of export authorizations and licenses issued in respect of military or dual use goods. Such financial markers, on the one hand, will make it easy to trace cases where the "military or dual use" category is deliberately removed through multiple purchases and sales or where price of such goods is being manipulated (understated or overstated, depending on expected tax targets).

A similar approach is suggested for military or dual use technology exports. Special financial markers are to be applied to investments into R\&D companies in the areas related to military or dual use technologies. Such financial markers will be useful in establishing the real size of investments in the Ukrainian scientific sector and in identifying mechanisms by which official export contracts are evaded as military or dual use technologies are transferred out of Ukraine. Same financial markers should be applied to cash flows generated by scientific hubs and other entities (specifically venture companies) whose registered Standard Activity Classification Codes are 84.22 "Activity in the Defense Sector" or Class 72 "Research and Development," or who act as intermediaries in transfers of scientific technologies. This would substantially facilitate state control over circulation of military and dual use technologies and support credible assessment of research expenditure (and, accordingly, estimated value of a technology) and identification of investment mechanisms used to minimize tax. 


\section{Conclusions}

We can generally conclude from our research that in the past 5 years Ukraine saw a substantial increase in both the government military expenses (a nearly threefold growth) and expenditure for research related to military and dual use technologies (grown almost five times). At the same time, the cost dimension of military and dual use technology exports in the same period has seen substantial decline (from 600 million USD to 90 million USD), although domestic consumption of military and dual use goods has grown only by $70 \%$. This indicates growth in the gray exports of military and dual use goods, the expansion of the domestic black market of military and dual use goods, and the increase of the concealed export of military and dual use technologies. Our research suggests that the total amount of the gray market of military and dual use goods exceeds 400 million USD. In order to make this segment transparent we suggest applying FinTech tools - BlockChain markers - to record information on all counterparts and conditionally affiliated companies related to cash flows from sales of military or dual use goods. Similar financial markers are suggested in respect of investments directed into companies or other entities involved in research and development in the area of military or dual use technologies. This approach will enable tracing all stages of military and dual use good and technology transfers and detection of illicit activity related to military and dual use goods and technologies, such as their reclassification as being non-military or non-dual use or manipulations with military or dual use goods prices.

\section{References:}

Androshchuk, G. (2018). Technology Transfer in Ukrainian Defense Industry: Problem Issues (Part I). Science, Technology, Innovations, vol. 1, pp. 62-71.

Anokhin, I., \& Davydovskyy, A. (2015). Special Aspects of State Export Control over International Transfers of Nuclear Material, Equipment and Technologies in Ukraine. Nuclear Physical and Power, vol. 1(16), pp. 98-105.

Galaka, S., Perepelytsia, G., \& Siver, O. (2012). Export Control as Part of International Security. Kyiv: KNU.

SSECU (2018). Restrictions to be Met or Accounted by Ukraine in Military and Technical Cooperation with Foreign States. State Service for Export Control of Ukraine. Available at: https://cutt.ly/Fj1LRJt (accessed: 20.07.2020).

The Law of Ukraine (2003). On State Control of International Transfers of Military and Dual Use Goods. Available at: https://zakon.rada.gov.ua/laws/show/549-15\#top (accessed: 20.07.2020).

Klymchuk, O. (May 2020). Illegal Weapons in Ukraine: Numbers and Ways of Recovery. Deutsche Welle. Available at: https://www.dw.com/uk/ (accessed: 20.07.2020).

Markevych, K. (2020). Who Invests in Ukraine and How. Razumkov Center. Available at: http://razumkov.org.ua/ statti/khto-i-iak-investuie-v-ukrainu (accessed: 20.07.2020).

Mochernyi, S. (2000). Economic Encyclopedia. Volume 1. Kyiv: Academia Publishing Center.

Popovych, D. (November 2019). Tanks for Zelensky: Questions Risen by President's Visit of Kharkov. Ukrrudprom. Available at: http://www.ukrrudprom.com/digest/Tanki_Zelenskogo_kakie_voprosi_vizval_ vizit prezidenta_v_Harkov.html (accessed: 20.07.2020).

Fradinsky, O. (2013). State Export Control. Customs Encyclopedia. In Two Volumes. Volume 1. Khmelnytsky: PE A. Melnyk.

Shtepenko, K., \& Zaburayeva, O. (2019). Analysis of Direct Foreign Investments in Ukrainian Economy and Need for Their Attraction. Effective Economy, vol. 5. doi: 10.32702/2307-2105-2019.5.34

Michel, Q. (2017). Regional rules and policies. Legally and Politically Binding Acts: the European Union. Introduction to International Strategic Trade Control Regimes. European Studies Unit. Available at: http://www.esu.ulg.ac.be/49/pdf/iistcr/3_part.pdf (accessed: 19.07.2020).

Revenko, N. (2016). Eternal Dilemma: "Nonproliferation - Competitiveness". 1540 Compasss, issue 10. Available at: http://cits.uga.edu/1540compass (accessed: 20.07.2020).

Ham, P. van (2014). Transnational Governance and Democratic Legitimacy, The Case of WMD Proliferation. EU Non proliferation Consortium. Available at: https://www.nonproliferation.eu/transnational-governance-anddemocratic-legitimacy-the-case-of-wmd-proliferation/ (accessed: 20.07.2020). 